\title{
Valorization of Aluminum Dross with Copper via High Temperature Melting to Produce Al-Cu Alloys
}

\author{
Artur Kudyba ${ }^{1, * \mathbb{C}}$, Shahid Akhtar ${ }^{2}$, Inge Johansen ${ }^{2}$ and Jafar Safarian ${ }^{1}$ \\ 1 Department of Materials Science and Engineering, Norwegian University of Science and Technology (NTNU), \\ Alfred Getz Vei 2, 7034 Trondheim, Norway; jafar.safarian@ntnu.no \\ 2 Hydro Aluminum, Romsdalsvegen 1, 6600 Sunndalsøra, Norway; shahid.akhtar@hydro.com (S.A.); \\ inge.johansen@hydro.com (I.J.) \\ * Correspondence: artur.kudyba@ntnu.no; Tel.: +47-462-44-097
}

Citation: Kudyba, A.; Akhtar, S.; Johansen, I.; Safarian, J. Valorization of Aluminum Dross with Copper via High Temperature Melting to Produce Al-Cu Alloys. Materials 2021, 14, 4117. https://doi.org/10.3390/ ma14154117

Academic Editor: Hansang Kwon

Received: 10 June 2021

Accepted: 20 July 2021

Published: 23 July 2021

Publisher's Note: MDPI stays neutral with regard to jurisdictional claims in published maps and institutional affiliations.

Copyright: (c) 2021 by the authors. Licensee MDPI, Basel, Switzerland. This article is an open access article distributed under the terms and conditions of the Creative Commons Attribution (CC BY) license (https:// creativecommons.org/licenses/by/ $4.0 /)$.

\begin{abstract}
The valorization of aluminum dross for $\mathrm{Al}$ recovery was performed via its mixing with metallic copper to produce Al-Cu alloys. This approach was with the intention of establishing a new smelting process to treat the dross with $\mathrm{Cu}$ scrap use. To evaluate the high temperature interaction of the materials, the wettability of a Cu-containing aluminum alloy with the non-metallic components of the dross was studied by the sessile drop method. It was found that the wetting was weak via temperature changes at $973-1373 \mathrm{~K}$, and consequently no proper metal separation occurred. To better separate the metallic and non-metallic phases with larger density differences, a higher Cu portion was considered to obtain a significantly denser metallic phase, and it was found that partial separation of the $\mathrm{Al}$ in an $\mathrm{Al}-\mathrm{Cu}$ alloy is possible. The complete separation of the metallic components of the dross was, however, experienced by the dross and copper melting with the addition of pre-melted calcium aluminate slags at elevated temperatures. It was found that $\mathrm{Al}-\mathrm{Cu}$ alloys were produced and separated from the adjacent slags, and the aluminum oxide of the dross ended up in the slag phase. Moreover, the characteristics of the produced slags depend on the process charge.
\end{abstract}

Keywords: Al dross; wettability; white dross; contact angle; aluminum recovery; sessile drop

\section{Introduction}

Aluminum alloys are light, conductive, and corrosion resistant, properties that have made them a widely used material with applications in the aerospace, architectural construction, and marine industries, as well as in many domestic contexts [1,2]. Pure aluminum is the Earth's third most abundant element, accounting for about $8 \%$ of the mass of the Earth's crust, and it never occurs as a free element in nature [3,4]. At present, aluminum is mainly produced via two different methods: (I) a primary aluminum production from bauxite ore via the Bayer process for alumina extraction, followed by Hall-Heroult electrolysis for $\mathrm{Al}$ extraction from alumina, and (II) by recycling aluminum from process scrap and used aluminum products [3-7]. The world's production of aluminum is increasing every year and was approx. 64 million metric tons in 2019 with a daily average of 174.5 thousand tons [3,7], while in 2020 it was over 65 million metric tons in 2020 [8]. As a result of the exposure of liquid aluminum to the oxidizing atmosphere that is present during the process of melting and alloying, a surface oxidation takes place, leading to the formation of a semisolid skin over the molten $\mathrm{Al}$ metal, which also hinders further oxidation [7]. This floating skin over liquid $\mathrm{Al}$ is called aluminum dross and consists mainly of aluminum oxide, metallic aluminum, magnesium spinel $\left(\mathrm{MgAlO}_{4}\right)$, periclase $(\mathrm{MgO})$, quartz $\left(\mathrm{SiO}_{2}\right)$, and salts with small traces of aluminum carbides and nitrides $[9,10]$. The recycling of $\mathrm{Al}$ dross, which is a by-product, is important from both environmental protection and economic points of view [4,6]. Generally, there are two types of Al dross: (I) White Dross (the primary dross) and (II) Black Dross (the secondary dross) [3,7]. 
Aluminum White Dross (AWD) forms during the primary production of aluminum and contains a high percentage of $\mathrm{Al}$ and $\mathrm{Al}_{2} \mathrm{O}_{3}$ i.e., around $75 \% \mathrm{Al}$, and below $5 \%$ of salts $[3,11]$. Aluminum Black Dross (ABD) consists of a low amount of metal substance and is formed at secondary aluminum production routes. ABD involves a mix of aluminum oxides and slag, with recoverable aluminum content is in the range $12-18 \%$ and a greater amount of salt substance; for instance, greater than $40 \%$ stood out from white dross [11-16]. Each year, the world's aluminum industry produces approximately four million tons (Mt) of AWD $[3,14]$. More than a million tons of ABD are reported throughout the world each year, and around $95 \%$ of this material, which is hazardous, is landfilled $[3,4,17]$. Aluminum dross is a potentially toxic industrial waste inevitably generated in aluminum smelter plants. The safe disposal of $\mathrm{Al}$ dross as a waste is a problem for the aluminum industry because of the effects of its improper disposal on the eco-system. Owing to the large annual production of $\mathrm{Al}$ dross and its environmental and economic impacts, aluminum dross undergoes industrial treatments to extract valuable products, including metallic aluminum [7]. Basically, two methods of Al dross treatment are used: (I) a pyrometallurgical, which is a conventional method of treating Al dross, liberating metallic aluminum in the liquid state; and (II) a hydrometallurgical, which involves an extraction of metallic aluminum from the Al dross by converting it into aluminum salts and compounds [3,7]. The metal extraction using pyrometallurgical process yields a good metal recovery rate. In the case of lower metallic content in dross, the hydrometallurgical process is preferred [18]. The recycling of aluminum dross is crucial for environmental protection, economic reasons, and sustainable development regarding circular economy [7].

The main purpose of the present work was to experimentally examine the effect of copper addition into AWD on the $\mathrm{Al}$ recovery from the white dross via a high temperature melting process with and without flux addition. In this case, the melting of AWD was with the goal of recovering the metallic $\mathrm{Al}$ in AWD in the form of $\mathrm{Al}-\mathrm{Cu}$ alloys. Moreover, the wetting behavior of a liquid Al-Si-Cu commercial alloy in contact with the nonmetallic components of AWD (solid Al dross substrate) was studied to obtain a proper understanding about the mechanisms of high-temperature interaction between liquid aluminum alloys with the non-metallic components of the AWD. A full understanding of this mechanism will allow for the effective separation of the metallic phase from the Al dross material (mainly oxide phases), which may contribute to more effective recycling of aluminum dross. The wetting and spreading behavior of liquid aluminum alloy on a surface of solid Al dross substrate is an important phenomenon that should be considered for improving the recycling of aluminum dross. Generally, the wetting of a solid by a liquid depends on the involving interfacial tensions between the three involved phases: solid/vapor (SV), solid/liquid (SL), and liquid/vapor (LV) [19]. A value of Young's contact angle $\theta_{Y}$ (Figure 1) is an ideal quantity, theoretically defined [20] from the mechanical equilibrium calculated for a liquid droplet contacting a substrate under the action of horizontal forces acting at the three-phase contact line (a so called triple line (TL)). These forces arise from the interfacial energies of the liquid/vapor $\sigma_{\mathrm{lv}}$, solid/vapor $\sigma_{\mathrm{sv}}$, and solid/liquid $\sigma_{\mathrm{sl}}$ interfaces [21]. Consequently, these considerations are summarized by the Young equation [20]:

$$
\sigma_{\mathrm{sv}}-\sigma_{\mathrm{sl}}=\sigma_{\mathrm{lv}} \cos \theta,
$$

A detailed description of Young's equation, the sessile drop method, and corresponding testing procedures are reviewed and available in Refs. [22,23]. 


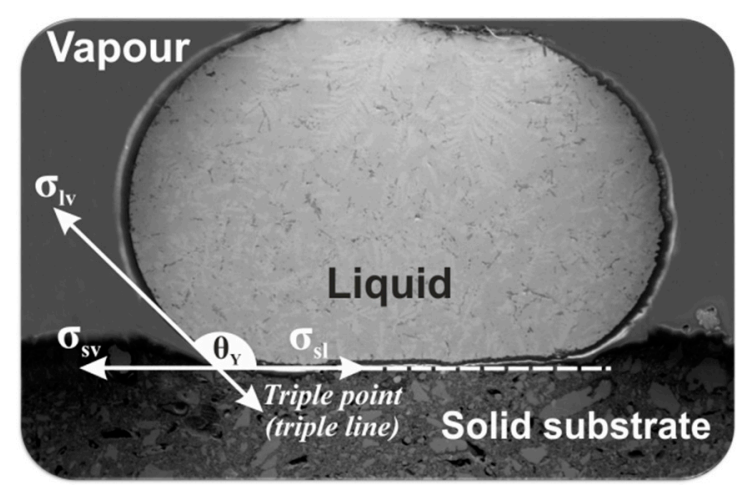

Figure 1. A scheme showing the concept of Young's contact angle $\theta_{Y}$ for a sessile drop contacting a solid surface.

\section{Experimental Procedure}

The materials preparation and applied methodology are described as follows.

\subsection{Materials and Sampling}

\subsubsection{Wettability Test}

The substrate for the wettability tests was performed from a commercial AWD (Hydro Aluminum, Sunndalsøra, Norway) with a particle size below $1 \mathrm{~mm}$. AWD was first collected from the skimmed dross over the surface of molten primary $\mathrm{Al}$ and an $\mathrm{Al}-\mathrm{Si}-\mathrm{Mn}$ alloy (grade series 4000, respectively). To directly extract a representative Al dross sample, a special sampling tool was introduced into a dross tub, and when the Al dross was skimmed from the reverberatory furnace into the tub in which the tool was positioned in, a portion of the hot dross was collected. The aluminum dross was subsequently subjected to a ball milling, and a detailed description of this procedure is reviewed in Refs. [3,7]. After the milling process, the milled product was fractioned by sieving, and the material from the smallest fraction with a particle size below $1 \mathrm{~mm}$ was used to create the substrates as it has the majority of the non-metallic components of the AWD [3,7]. The metal sample used in the wettability tests was an alloy of Al-5.6\%Si-7.6\% $\mathrm{Cu}$ that was created by mixing a commercial Al-Si-Cu alloy (92.6 wt.\% Al, 6.7 wt.\% Si, 0.47 wt.\% Cu, 0.35 wt.\% Mg, 0.15 wt.\% Fe, 0.09 wt. $\%$ Mn) with pure copper (99.99\%).

\subsubsection{Melting Trials}

The above AWD was used for the melting tests; however, a particle size of 2-10 mm was used. In experiment 1 , only the dross particles and $\mathrm{Cu}$ particles were mixed, with no flux addition. In experiments 2 and $3, \mathrm{a} \mathrm{CaO}-\mathrm{Al}_{2} \mathrm{O}_{3}$ synthetic-slag flux was added. Two different slag compositions were initially prepared: $\mathrm{CaO} / \mathrm{Al}_{2} \mathrm{O}_{3}=2$ (experiment 2 ) and $\mathrm{CaO} / \mathrm{Al}_{2} \mathrm{O}_{3}=4$ (experiment 3 ) via mixing pure $\mathrm{CaO}$ and $\mathrm{Al}_{2} \mathrm{O}_{3}$ powders (above $99 \%$ purity level), and then melting them in a top-open induction furnace at $1873 \mathrm{~K}$ in a graphite crucible (Svenska Tanso AB, Jönköping, Sweden) for $1 \mathrm{~h}$. For the AWD melting trials, metallic $\mathrm{Cu}(99.99 \%)$ particles were added with sizes of $1-5 \mathrm{~mm}$, and the charge mixture details are given in Table 1.

Table 1. The charge mixture details.

\begin{tabular}{ccccc}
\hline \multirow{2}{*}{ Exp. Number } & Al Dross (g) & Cu Metal (99.99\%) (g) & \multicolumn{2}{c}{ Synthetic Slag (g) } \\
\cline { 3 - 5 } & & & $\mathbf{C a O}$ & - \\
2 & 16.2 & 24.26 & - & 8.40 \\
3 & 75.17 & 150.13 & 16.87 & 5.06 \\
\hline
\end{tabular}




\subsection{Melting Procedure}

\subsubsection{Wettability Test}

The wettability experiment of the $\mathrm{Al}-\mathrm{Si}-\mathrm{Cu} / \mathrm{Al}$ dross couple was carried out by the classical Sessile Drop (SD) method combined with a newly introduced Capillary Purification (CP) procedure (Łukasiewicz Research Network-Krakow Institute of Technology, Kraków, Poland, Figure 2a) that allows for the purification of the reactive molten metal drop from its surface oxide layer. The native oxide film was mechanically removed during the squeezing of the liquid $\mathrm{Al}$ alloys-drop from the capillary (Figure 2a), which allowed for the measurement of true contact angle values. The Al-Si-Cu/Al dross couple was subjected to an SD experiment that was performed using the experimental device (for investigation of high-temperature capillary phenomena of liquid metals and alloys) described elsewhere [24,25].

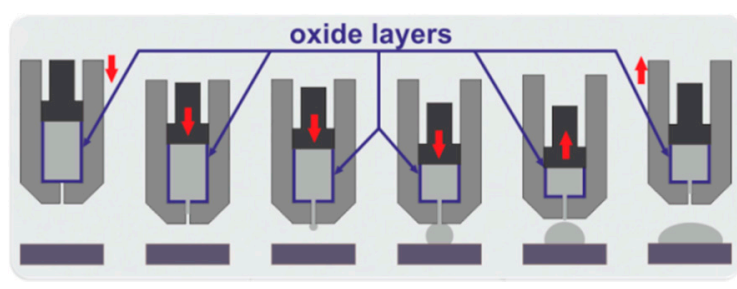

(a)

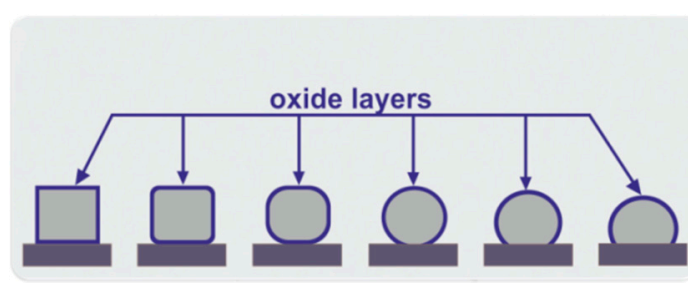

(b)

Figure 2. A scheme of the high-temperature wettability test by classical Sessile Drop method (SD) combined with procedure: (a) Capillary Purification (CP); (b) Contact Heating (CH) [21-25].

The wettability experiment included 6 intervals at $1373 \mathrm{~K} / 5 \mathrm{~min}, 1173 \mathrm{~K} / 5 \mathrm{~min}$, $1123 \mathrm{~K} / 5 \mathrm{~min}, 1073 \mathrm{~K} / 5 \mathrm{~min}, 1023 \mathrm{~K} / 5 \mathrm{~min}$, and $973 \mathrm{~K} / 5 \mathrm{~min}$. The main purpose of this test was to examine the effect of testing temperature on the wetting characteristics and to establish applicability limits of selected materials. The exact diagram of the temperature profile used in the wettability experiment is shown in Figure 3.

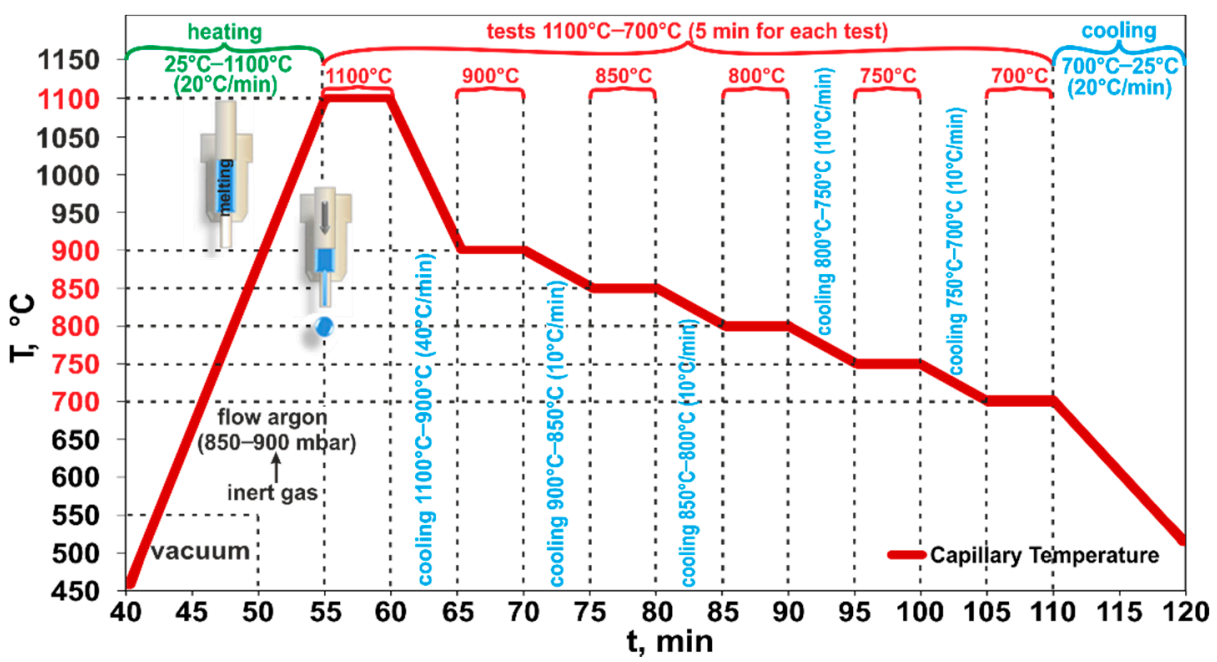

Figure 3. Temperature profile of the high-temperature wettability test of the Al-Si-Cu/Al dross couple carried out by a step-cooling with six intervals.

After placing the alloy/substrate couple inside the chamber, gases were evacuated using Scroll (Duo 10M, Pfeiffer Vacuum Gmbh, Asslar, Germany) and turbo-molecular pumps (TW 701, Leybold Vakuum Gmbh, Köln, Germany). When pressure inside the chamber reached the value of about $1 \times 10^{-6} \mathrm{mbar}$, heating was started at a rate of $293 \mathrm{~K} / \mathrm{min}$ to test temperature $1373 \mathrm{~K}$ (Figure 3). At a temperature of $823 \mathrm{~K}$, the inert gas (flowing argon, $p=850-900$ mbar) was introduced to the chamber to suppress the evaporation from 
the Al-Si-Cu alloy. During the experiments, the $\mathrm{Al}-\mathrm{Si}-\mathrm{Cu} / \mathrm{Al}$ dross couple images were recorded by a high-speed digital CCD camera (Microtron MC 1310, Microtron GmbH, Unterschleißheim, Germany) at 50 frames per second, and then the images were processed to measure the change of contact angle values over time and to analyze the related wetting kinetics by using ASTRA 2 software. After the high temperature tests, the solidified couple was removed from the chamber and subjected to a structural characterization of the prepared cross sections by using the Zeiss Ultra 55 Scanning Electron Microscope (SEM, Carl Zeiss Microscopy GmbH, Jena, Germany), coupled with energy-dispersive X-ray spectroscopy (EDS, Carl Zeiss Microscopy GmbH, Jena, Germany).

\subsubsection{Melting of $\mathrm{Al}$ Dross with $\mathrm{Cu}$ and Synthetic Slag}

In experiment $1, \mathrm{Al}$ dross was mixed with pure $\mathrm{Cu}$ in the mass proportions of $40 \%$ and $60 \%$, respectively. The mixture was charged into an alumina crucible and then in a graphite crucible, as schematically shown in Figure 4a.

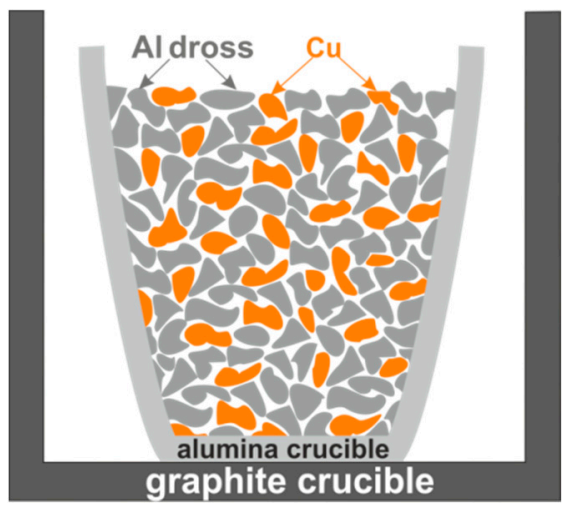

(a)

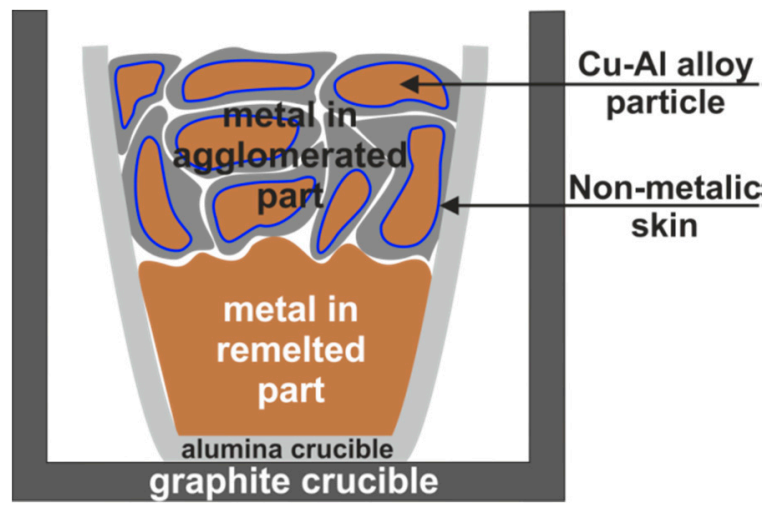

(b)

Figure 4. A scheme of (a) charged materials for experiment 1 in-crucible before the reaction test, and (b) the produced metal in agglomerated and remelted parts after the reactions.

The mixture in the crucible was subjected to annealing at a temperature of $1373 \mathrm{~K}$ for $30 \mathrm{~min}$ in a top-open induction furnace (Cold Crucible, NTNU, Trondheim, Norway) described elsewhere [3,7] in a protective atmosphere (flow gas Ar 5.0 at a constant pressure of $1030 \mathrm{mbar}$ ), resulting in melting of the metallic components. After melting, the furnace power was turned off and, consequently, the molten components solidified. The remelted and separated metal moved to the bottom of the crucible, while the agglomerated part remained above it, as schematically illustrated in Figure $4 \mathrm{~b}$. The produced remelted metal and the agglomerated part were separated after breaking the crucibles. Metallography samples were then created from them by mounting in epoxy resin followed by grinding and polishing. The structure and chemical composition of different phases were determined by using the same SEM/EDX mentioned above.

For experiments 2 and $3, \mathrm{Al}$ dross was mixed with $\mathrm{CaO}-\mathrm{Al}_{2} \mathrm{O}_{3}$ synthetic slags (Table 1). The mixtures were first charged into alumina crucibles and pure $\mathrm{Cu}$ was deposited on the top of these mixtures, and then they were put in graphite crucibles as schematically shown in Figure 5a. 


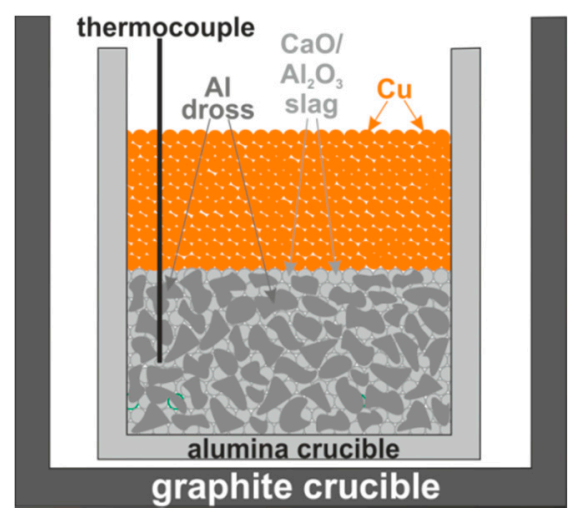

(a)

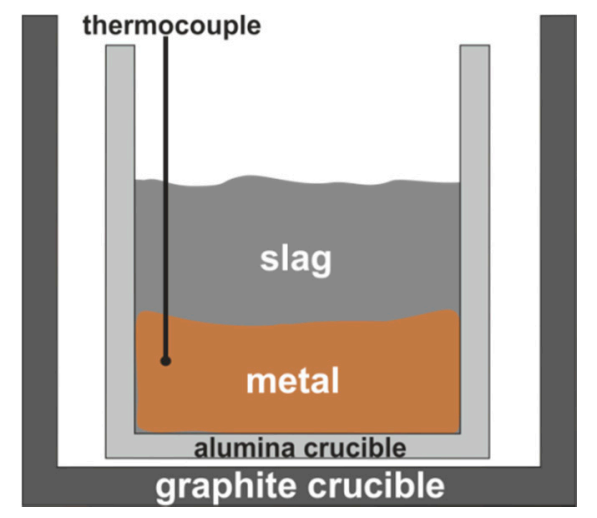

(b)

Figure 5. A scheme of (a) charged materials for experiments 2 and 3 in-crucible before the reaction test, and (b) the produced slag and metal after the reactions.

The crucibles with the charge mixtures were put in an induction furnace and a thermocouple was put into the charge mixture to measure the temperature inside the crucible. Each crucible was heated at about $293 \mathrm{~K} / \mathrm{min}$ up to $1773 \mathrm{~K}$ and held for $30 \mathrm{~min}$ in a protective atmosphere (flow gas Ar 5.0 at a constant pressure of 1030 mbar). After melting, the furnace power was turned off and, consequently, the molten components solidified. The metal was much heavier than the slag and it sunk down to the crucible's bottom, as schematically illustrated in Figure $5 \mathrm{~b}$. The produced metal and slag were separated after breaking the crucibles and subjected to a structural characterization by SEM/EDX. Moreover, the produced final slags from experiments 2 and 3 were studied by X-Ray Diffraction (XRD) analysis using a Bruker D8 A25 DaVinci X-ray Diffractometer with CuK $\alpha$ radiation with LynxEye ${ }^{\mathrm{TM}}$ SuperSpeed Detector (Bruker Corporation, Billerica, MA, USA) [26,27].

\section{Results and Discussion}

The obtained results are presented and discussed as follows.

\subsection{Wetting Behaviour of Al Dross Substrate}

Figure 6a shows macro views of the Al-Si-Cu/Al dross couple after the wettability test and the results of the SEM and EDS microstructural analyses of the cross sectioned sample (Figure $6 \mathrm{~b}-\mathrm{e}$ ). A regular round shape of the Al-Si-Cu drop solidified on the $\mathrm{Al}$ dross substrate was observed. The solidified metal drop was located in the central part of the substrate and was characterized by a smooth and shiny surface devoid of the oxide layer (Figure 6a), which was the result of the $\mathrm{CP}$ procedure used in the wettability test. Typical SEM images from the metal/dross interfacial area are given in Figure 6b-e, and selected areas were analyzed by the EDS. The dark grey phase in the SEM images of Figure $6 \mathrm{~b}-\mathrm{e}$ shows the presence of a dominant phase of metal matrix in the drop that consists mainly of $\mathrm{Cu}$ and $\mathrm{Al}$ elements. The results of local chemical composition analyses by EDS from three areas 1, 5 (Figure 6d) and 7 (Figure 6e) revealed that it was composed of an average of $54.7 \mathrm{wt} . \% \mathrm{Cu}$ and $42.8 \mathrm{wt} . \% \mathrm{Al}$. According to the Al-Cu phase diagram [28], the metal contained a matrix structure of $\theta-\mathrm{CuAl}_{2}$ phase in these areas. The presence of a second dominant phase consisting of the $\mathrm{Cu}$ and $\mathrm{Al}$ elements was also found for the light grey phase that was analyzed by EDS analysis at four areas 2, 4 (Figure 6d), and 8, 10 (Figure 6e). The analysis revealed that it was mainly composed of an average of $72.3 \mathrm{wt} . \%$ $\mathrm{Cu}$ and $26.1 \mathrm{wt} . \% \mathrm{Al}$. Based on the results of the EDS evaluations and considering the Al$\mathrm{Cu}$ phase diagram [28], it is concluded that the chemical composition of light grey phase corresponds to the $\eta$-CuAl phase. Moreover, a needle-like Si phase (point 3 in Figure $6 \mathrm{~d}$ and point 6 in Figure 6e) was also identified, containing an average of $98.2 \mathrm{wt} . \% \mathrm{of} \mathrm{Si}$; these could be primary Si particles that formed during the solidification of the Al-Si-Cu alloy. The identified small amount of oxygen could be due to the surface oxidation of the metal 
phase during cutting and sample preparation. An important result was that the commercial Al dross substrate did not give significant impurities to the metal sample.

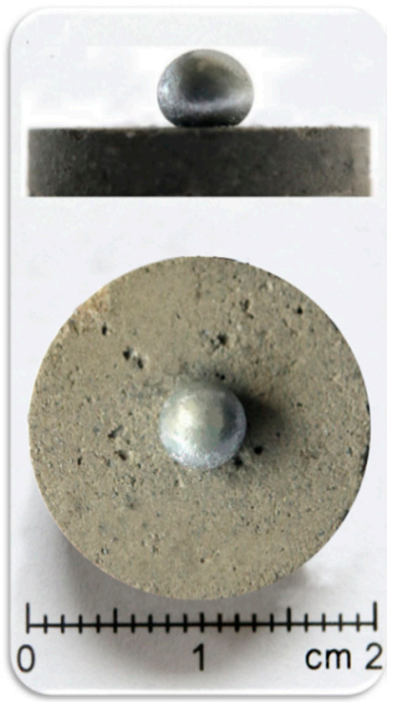

(a)

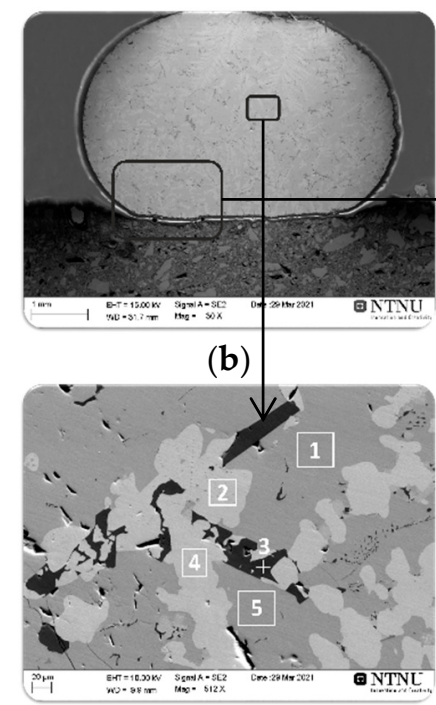

(d)

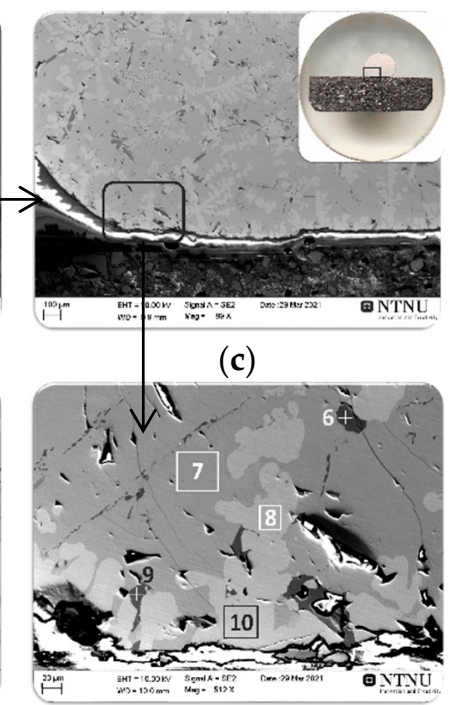

(e)

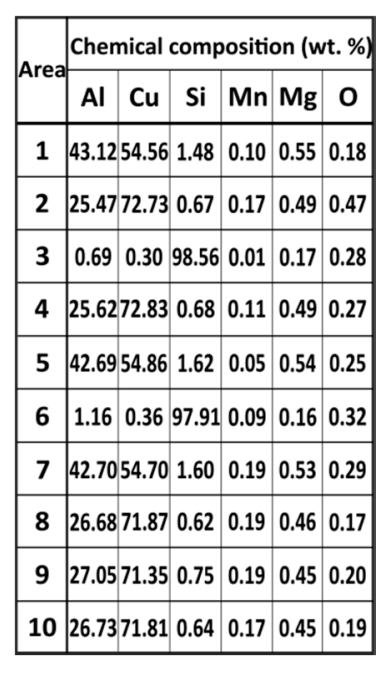

(f)

Figure 6. The macro views of Al-Si-Cu/Al dross couples after the wettability test (a) and the results of the SEM/EDS microstructural analyses of the cross sections of sample at magnification $30 \times(\mathbf{b}) ; 89 \times(\mathbf{c})$; and $512 \times(\mathbf{d}, \mathbf{e})$; EDS (f).

The side view of the sample in Figure 6a shows that the dross had not been wetted by the Al alloy. Figure 7 shows the results of high-temperature wetting behavior of liquid Al$\mathrm{Si}-\mathrm{Cu}$ alloy in contact with $\mathrm{Al}$ dross substrate by applying the $\mathrm{CP}$ procedure at temperatures $1373,1173,1123,1073,1023$, and $973 \mathrm{~K}$, for $5 \mathrm{~min}$ at each of the temperatures. It was found that the contact angle values were very high in the whole examined temperature range and they slightly decreased from $\theta_{1373}=130^{\circ}$ to $\theta_{973}=128^{\circ}$ (Figure $7 \mathrm{~b}$ ), with decreasing testing temperature from 1373 to $973 \mathrm{~K}$, respectively. The wetting kinetics curve of the studied Al-Si-Cu alloy/Al dross system was constant and showed a plateau at each of the tested temperatures (Figure 7a). Based on the analysis of the wetting kinetic curve (Figure 7a) and values of the contact angle after 5 min for six temperature intervals (Figure 7b), it can be concluded that the temperature change in the range of 1373 to $973 \mathrm{~K}$ does not affect the wettability of the Al-Si-Cu alloy/Al dross system, i.e., the value of the contact angle does not change. It should be noted that the contact angles measured after 5 min holding at each consecutive temperature cycle presented very high values and they were significantly higher than $90^{\circ}$, i.e., the wettability criteria, which proves that the Al-Si-Cu alloy/ $\mathrm{Al}$ dross couple is a non-wetting system.

In all the former studies [29-47], no significant work was performed on studying the wetting behavior of liquid Al-Si-Cu alloy in contact with Al dross substrate with particular emphasis on the $\mathrm{CP}$ procedure. Hence, the novelty of the present study is first providing wettability information of $\mathrm{Al}-\mathrm{Si}-\mathrm{Cu} / \mathrm{Al}$ dross systems, secondly the application of the CP procedure in the Al dross wettability test, and third providing microstructural information of Al-Si-Cu/ Al dross systems. Literature survey [29-47] revealed that available papers are mostly concerned with the study of the wettability of pure $\mathrm{Al}$ [29-37] and its alloys [38-45] in contact with various types of substrates, such as $\mathrm{Al}_{2} \mathrm{O}_{3}[29,34], \mathrm{TiO}_{2}[30,34]$, $\mathrm{C}[31,38,40,44], \mathrm{NiO}$ [32], $\mathrm{SiC}[33,39], \mathrm{ZrO}_{2}$ [34], $\mathrm{CoO}$ [35], $\mathrm{ZnO}$ [36], $\mathrm{Y}_{2} \mathrm{O}_{3}$ [37], $\mathrm{SiO}_{2}$ [46], and $\mathrm{MgO}$ [47]. In general, the wettability of $\mathrm{Al}$ and its alloys is better on carbon and carbides than on the oxides. Klinter et al. [42] analyzed the wetting behavior of Al-Cu alloys (Al$4 \mathrm{Cu}, \mathrm{Al}-7 \mathrm{Cu}, \mathrm{Al}-11 \mathrm{Cu}, \mathrm{Al}-33 \mathrm{Cu}$ ) on sapphire substrates by the SD method combined with a Contact Heating $(\mathrm{CH})$ procedure (Figure 2b) at 943, 973, 1003, 1023, and $1073 \mathrm{~K}$, in high vacuum. Since the native oxide film cannot be removed from Al-Cu drop using of the $\mathrm{CH}$ procedure, they had to increase the testing temperature up to $1073 \mathrm{~K}$. By taking into 
account thermodynamic considerations, at such temperatures the oxide layer at the surface of the liquid Al-Cu drop was thermally removed. The authors reported that sapphire was not wettable by liquid Al-4Cu alloy in the temperature range 943-973 $\mathrm{K}$ and the decrease of the contact angle $\theta$ was observed from $122^{\circ}$ to $92^{\circ}$, respectively. Further decreasing of the contact angle $\theta$ to the final value of $85^{\circ}$ was observed by increasing the temperature up to $\mathrm{T}=1073^{\circ} \mathrm{C}$ and after a holding time of $15 \mathrm{~min}$. The same problem of the oxide layer on the surface of liquid Al-Si drop was described by Mao et al. [44], who analyzed the wetting behavior of Al-Si alloys (Al-6Si, Al-10Si, Al-20Si) on graphite substrates by the $\mathrm{SD}$ method combined with the $\mathrm{CH}$ procedure (Figure $2 \mathrm{~b}$ ) in the temperature range of 1023-1273 $\mathrm{K}$, under a high vacuum atmosphere. They reported that at $1023 \mathrm{~K}$ the contact angle $\theta$ was very large, close to $160^{\circ}$, which corresponded to an oxidized surface surrounding the drop. Increasing the temperature to $1273 \mathrm{~K}$ caused the contact angle $\theta$ to decrease rapidly to about $124^{\circ}$, and then after $45 \mathrm{~min}$ at $1273 \mathrm{~K}$ the contact angle $\theta$ decreased to 86,83 , and $61^{\circ}$ for the Al-6Si/C, Al-10Si/C, and Al-20Si/C systems, respectively. However, upon testing at temperatures much higher than the melting point of the tested materials, the substantial evaporation of the material should be carefully considered in order to limit the contamination of the experimental environment and to protect the apparatus against severe damage. In addition, a strong material evaporation increases the ratio of the solid base diameter to solid height which, in case of reactive phenomena at the interface, makes the chemical-physical meaning of the measured contact angle values "apparent" [25]. Figure 8 shows the comparison of the present work's results with selected literature, and, as seen, the contact angle measurements in the present work were close to the $\mathrm{Al} / \mathrm{Al}_{2} \mathrm{O}_{3}$ results $[29,34]$; this may be due to the existence of $\mathrm{Al}_{2} \mathrm{O}_{3}$ as the main non-metallic component in the utilized dross.

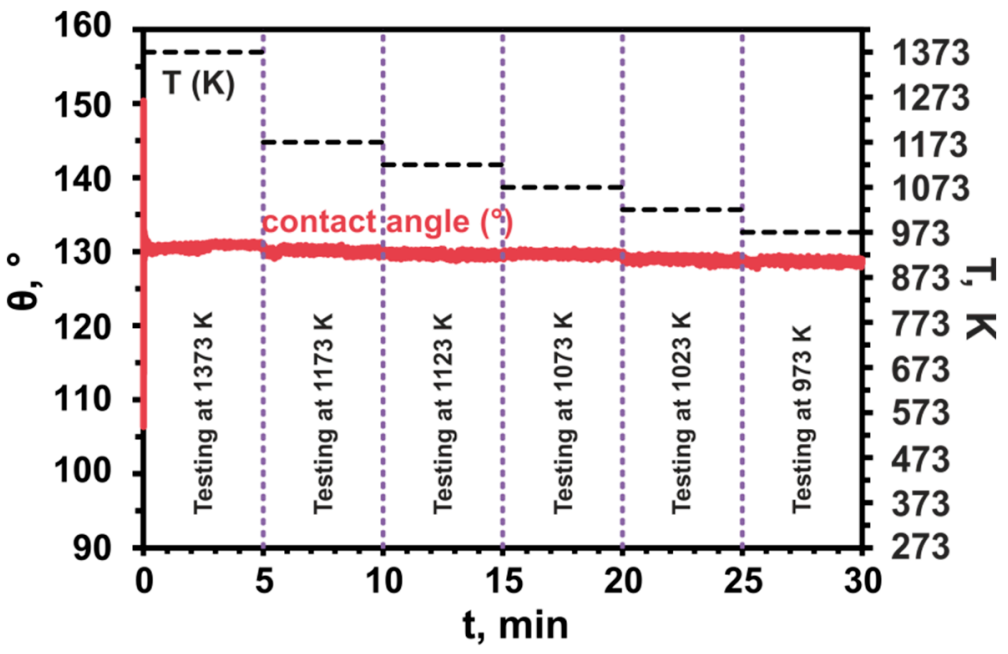

(a)

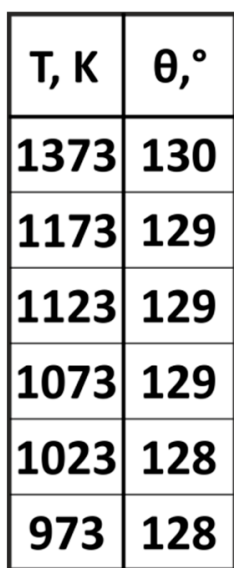

(b)

Figure 7. The results of high-temperature wetting behavior of Al-Si-Cu alloy/Al dross couple: (a) wetting kinetics curve (contact angle vs. time); (b) values of the contact angle after $5 \mathrm{~min}$ for six temperature intervals.

The above findings are very important to understand the mechanisms of high-temperature interaction between liquid $\mathrm{Al}-\mathrm{Si}-\mathrm{Cu}$ alloy/ $\mathrm{Al}$ dross systems when the remelting of the dross is performed. Non-wetting of the liquid Al-Si-Cu alloy in contact with $\mathrm{Al}$ dross substrate will not allow the effective separation of the metallic phase (through accretion) from the remaining non-metallic part. It was previously observed that melting of separated Al-rich particles of the dross does not yield the complete separation of the $\mathrm{Al}$ [3]. Obviously, the low Al recovery may be due to the low wetting of Al by the non-metallic components of the dross as observed above. This low wetting causes the melted Al portion of the dross to be distributed in a solid or semi-solid nonmetallic matrix and with unsuccessful accretion to 
acquire a metal separated from the nonmetallic phase. In the slat-based remelting process, however, the use of salt improves the wetting properties as the non-metallic components of the dross. The molten salt interaction with the non-metallic components of the dross yields a low viscous molten/semi-molten phase. This causes low interfacial tensions between the molten salt and the molten $\mathrm{Al}$, and hence the $\mathrm{Al}$ recovery is significantly enhanced. In the present work, however, a salt-free process for Al recovery from the dross was studied and, therefore, the melting trials were performed without any salt use.

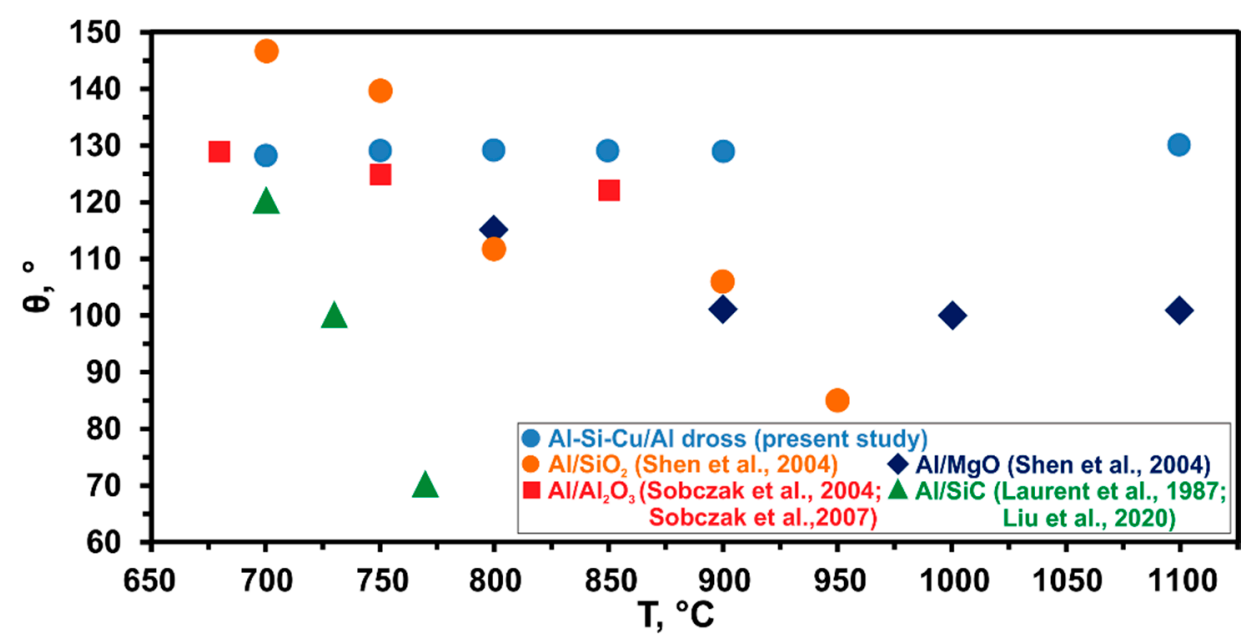

Figure 8. Comparison of the obtained values of the contact angle of the tested Al-Si-Cu/Al dross system with the reported in literature values of the $\mathrm{Al} /$ substrates systems, with a contact time of $5 \mathrm{~min}$ and at various temperatures $[29,33,34,41,46,47]$.

\subsection{Melting Behavior of Al Dross and Cu Mixtures}

The melting of separated Al-rich particles of the dross was performed in two approaches via changing the physical properties in the system for both the metallic portion and the non-metallic portion. Therefore, melting was performed by $\mathrm{Cu}$ metal addition to change the overall metal composition significantly and to a high $\mathrm{Cu}$-containing alloy. Moreover, additional $\mathrm{CaO}-\mathrm{Al}_{2} \mathrm{O}_{3}$ slag flux was used to dissolve the non-metallic portion of the dross into a co-existing slag. These approaches were based on the results of wetting trials in Section 3.1, and further results from melting trials are presented and discussed as follows.

\subsubsection{Flux-Free Melting of Al-Rich Dross with $\mathrm{Cu}$}

Figure 9 shows macro views of the broken crucibles after the melting of the mixture of $\mathrm{Al}$ dross particles with pure $\mathrm{Cu}$ chips shown in Figure 4.

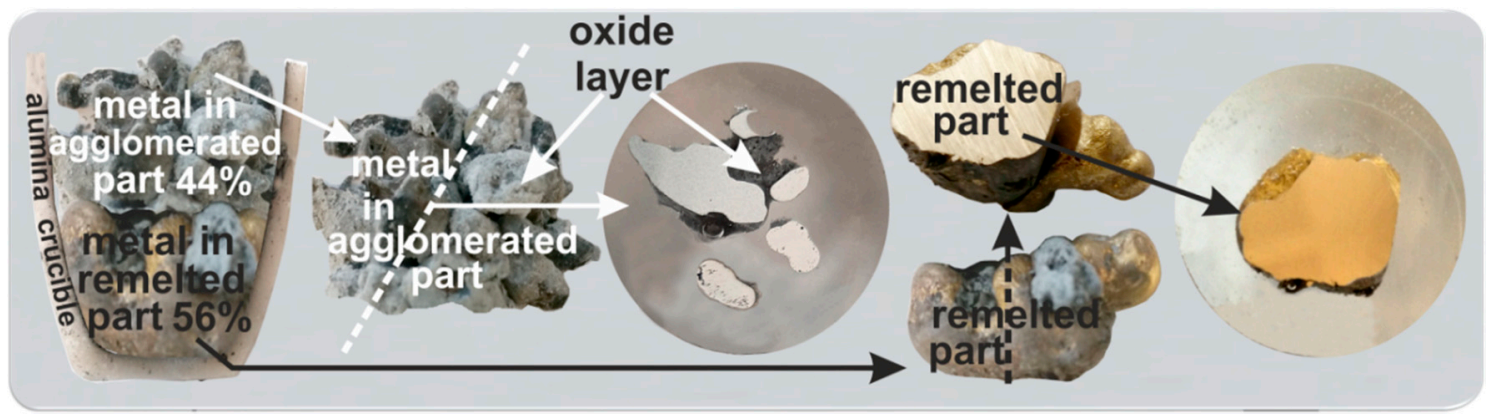

Figure 9. The broken crucibles after experiment 1 and the prepared sample for the SEM/EDX study. 
Considering the macro views of the broken crucible after remelting, the division of the sample into two areas is possible, namely the area of the agglomerated part on top and the complete remelted part on the bottom. The percentage masses of the agglomerated and melted parts were determined to be about $44 \%$ to $56 \%$, respectively. The induction melting of the mixture of $\mathrm{Al}$ dross with pure $\mathrm{Cu}$ contributed to homogenizing the structure of the completely remelted part, which consisted mainly of a metallic matrix of the copper-aluminum phase containing an average of $91 \mathrm{wt} . \% \mathrm{Cu}$ and $7 \mathrm{wt} . \% \mathrm{Al}$ (areas: 1, 3 in Figure 10a,b respectively). Obviously, most of the melted Al droplets (surrounded by an oxide layer) in the dross remained in the top agglomerated part and could join the copper to form a single melt in the crucible. This might be attributed to the role of surface aluminum oxide on the individual particles that act as a barrier and that could not be broken during the melting trial. This barrier was not a problem for the particles in the lower part of crucible due to higher intensity of the electromagnetic forces in this area, as the copper in the upper part had also been melted and a portion had moved down to the lower part. Moreover, the load from the materials from the upper part of the crucible charged to those in the lower part and higher local temperature in the bottom of crucible than the upper part contributed to this.

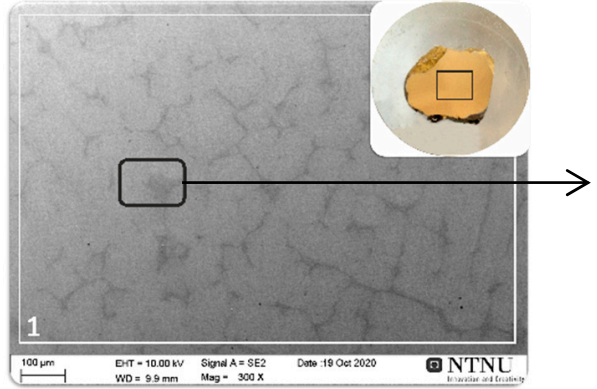

(a)

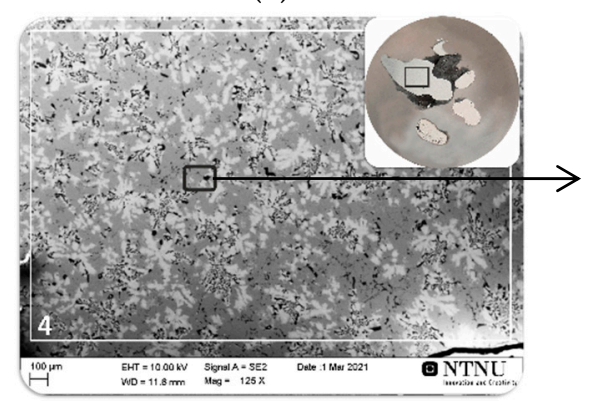

(c)

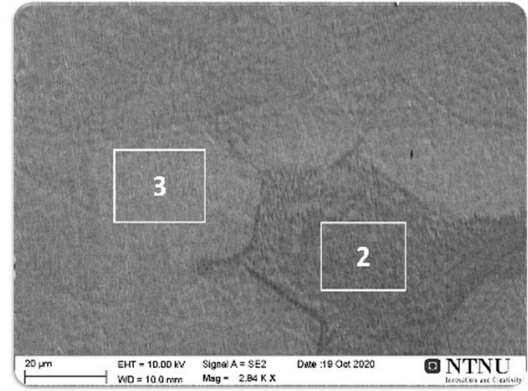

(b)

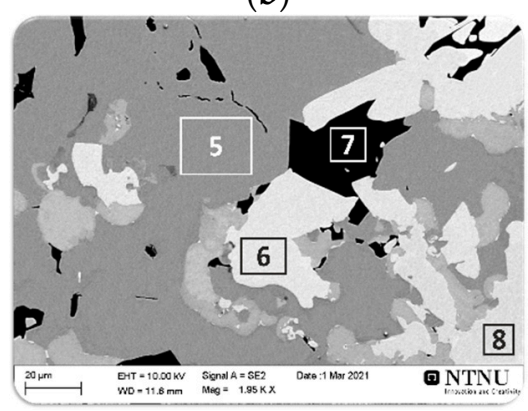

(d)

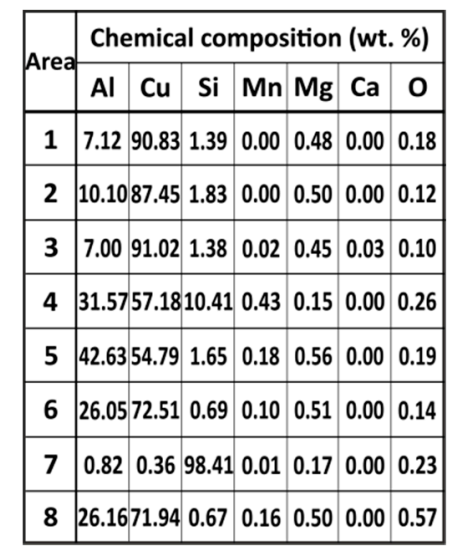

(e)

Figure 10. The SEM/EDS microstructural analysis of the cross-section of exp. 1 sample from remelted part $(\mathbf{a}, \mathbf{b})$ and agglomerated part (c,d); EDS (e).

The microstructural analysis of the agglomerated part showed the presence of three main phase (areas: 5, 6, 7 in Figure 10d). The dominant phase is a dark grey phase of a metallic matrix (Figure 10c), containing around $54.7 \mathrm{wt} . \%$ of $\mathrm{Cu}$ and $42.6 \mathrm{wt} . \%$ of $\mathrm{Al}$ as illustrated on area 5 in Figure 10d. Based on the EDS results (area 5 in Figure 10d) and considering the Al-Cu phase diagram [28], it is concluded that the chemical composition of this phase corresponds to the $\theta-\mathrm{CuAl}_{2}$ phase. The results of microstructural analysis of the light grey phase (area 6 in Figure 10d) revealed that it was composed of an average of 72.5 wt.\% Cu and 26 wt.\% Al. According to the Al-Cu phase diagram [28], the chemical composition of the light grey phase corresponds to the $\eta /-\mathrm{CuAl}$ phase. Area 7 in Figure $10 \mathrm{c}$ is a Si-rich phase containing around $98.4 \mathrm{wt}$.\% of Si. The presence of the Si phase resulted from the chemical composition of the Al-Si-Mn alloy from the surface of which the Al dross sample used in experiment 1 was collected. 
The overall chemical composition of the metallic portion in the agglomerated region shows that the $\mathrm{Al}$ content in this metal is much higher than that in the metal collected from the crucible's bottom. This can be observed through the comparison of areas 5 and 6 (in the agglomerated part) with areas 1 to 3 in Figure 10. It may be concluded that the $\mathrm{Al}, \mathrm{Si}$, and $\mathrm{Mn}$ dissolution into the molten copper on the upper parts occurred due to the significant electromagnetic stirring of the copper and hence mass transport of these elements from the semi-solid dross into the liquid copper. However, the separation of the metallic particles and settling down to the crucible's bottom did not occur. This is due to the contact of these metal droplets with the oxide part of the agglomerated material, which is a mixture of the metallic particles and nonmetallic material. The oxide network holds the metal droplets and prevents their separation due to the both gravity and the electromagnetic forces. In the lower part of the crucible, the same phenomena occurred; however, a rich copper metal was settled rapidly and its contact with the Al in the dross was prevented by the oxides present in the aluminum dross. This oxide layer over the metallic particles is seen in Figure 9. In short, a partial separation of Al through simple mixing of dross and copper followed by melting occurred. This process for better phase separation and $\mathrm{Al}$ recovery in the form of $\mathrm{Cu}-\mathrm{Al}$ alloys can be improved through mechanical stirring or by applying alternative melting methods such as by using a rotary furnace for enhanced mixing.

\subsubsection{Flux-Aided Melting of Al-Rich Dross with $\mathrm{Cu}$}

To overcome the challenges in metal separation through the simple induction melting described in Section 3.2.1, the slag-flux assisted melting experiments 2 and 3 were performed. The results for the melted $\mathrm{Al}$ dross with $\mathrm{CaO}-\mathrm{Al}_{2} \mathrm{O}_{3}$ synthetic slags and $\mathrm{Cu}$ indicated that, in experiments 2 and 3, two complete separable metal and slag phases were obtained, as shown in Figure 11, and this approach in return was more successful than experiment 1 . The metal phase was completely collected below the slag and the slag was easily separated from the metal due to no sticking between the two phases.

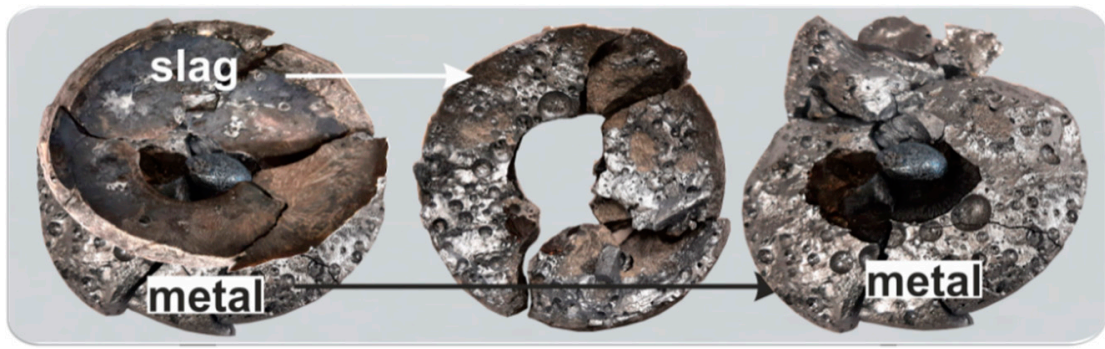

(a)

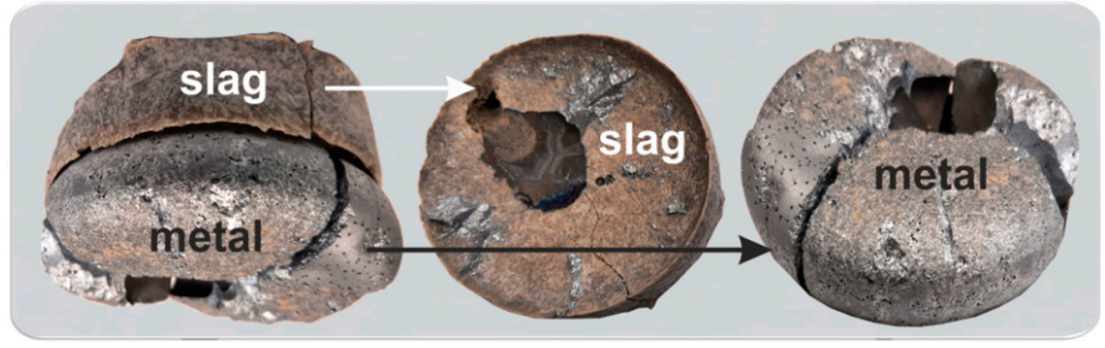

(b)

Figure 11. The samples after experiments: 2 (a) and 3 (b).

The results of SEM/EDS microstructural analysis of the cross-section of the metals and slags produced in experiments 2 and 3 are shown in Figure 12. Both metals have very close chemical compositions and they are ternary $\mathrm{Cu}$-Al-Si alloys with small amounts of $\mathrm{Mg}$ and Mn (areas: 1, 9 in Figure 12a,c respectively). The dominant phase is a light grey matrix (areas: 4, 10 in Figure 12a,c respectively), containing about 74 wt.\% of Cu and 24 wt.\% of 
Al. According to the Al-Cu phase diagram [28], the chemical composition of the dominant light grey phase corresponds to the $\mathrm{Al}_{3} \mathrm{Cu}_{4}$ phase. The microstructural analysis of the dark grey phase revealed that it was composed of an average of $54.7 \mathrm{wt} . \% \mathrm{Cu}$ and $42.4 \mathrm{wt} . \%$ $\mathrm{Al}$ (areas: 3, 11 in Figure 12a,c respectively). Considering the Al-Cu phase diagram [28], it is concluded that the chemical composition of the dark grey phase corresponds to the $\theta-\mathrm{CuAl}_{2}$ phase. In the microstructure Si-rich phase with about $98.4 \mathrm{wt} . \%, \mathrm{Si}$ (areas: 5 , 12 in Figure 12a,c respectively) was also found as a secondary precipitate, originated from the dross.

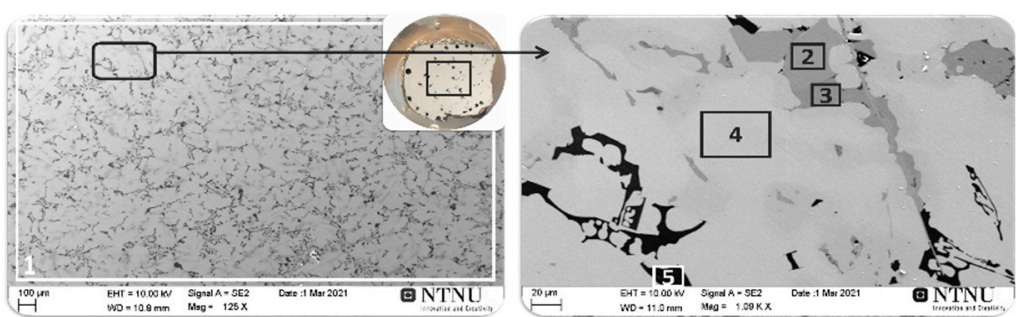

(a)

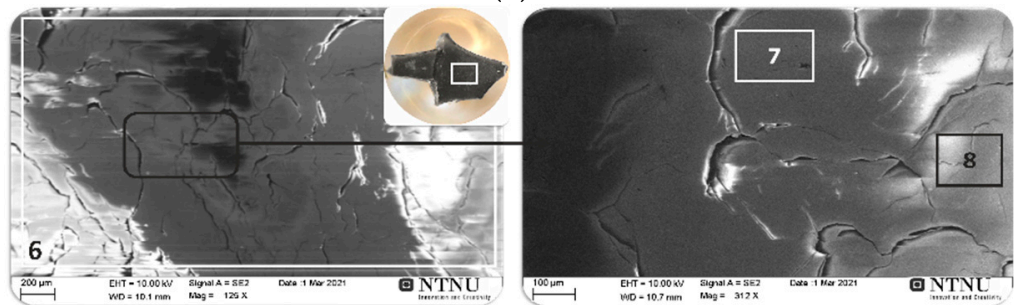

(b)

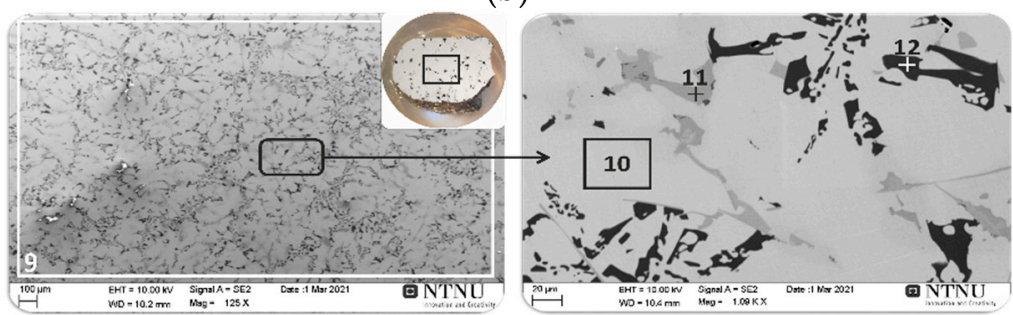

(c)

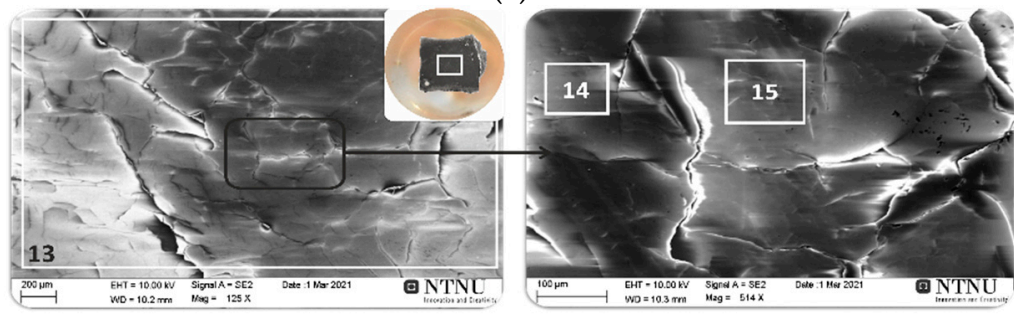

(d)

\begin{tabular}{|c|c|c|c|c|c|c|c|}
\hline \multirow{2}{*}{ Area } & \multicolumn{6}{|c|}{ Chemical composition (wt. \%) } \\
\cline { 2 - 7 } & Al & Cu & Si & Mn & Mg & Ca & O \\
\hline 1 & 21.55 & 67.22 & 10.22 & 0.20 & 0.44 & 0.10 & 0.27 \\
\hline 2 & 23.79 & 69.45 & 5.60 & 0.22 & 0.57 & 0.03 & 0.34 \\
\hline 3 & 42.3154 .70 & 1.74 & 0.37 & 0.73 & 0.00 & 0.15 \\
\hline 4 & 23.9874 .48 & 0.73 & 0.09 & 0.54 & 0.00 & 0.18 \\
\hline 5 & 0.71 & 0.43 & 98.47 & 0.02 & 0.16 & 0.00 & 0.21 \\
\hline 6 & 39.65 & 0.07 & 1.96 & 0.00 & 1.98 & 6.38 & 49.96 \\
\hline 7 & 39.86 & 0.12 & 1.98 & 0.00 & 1.96 & 6.19 & 49.89 \\
\hline 8 & 39.73 & 0.09 & 1.34 & 0.06 & 1.74 & 12.48 & 44.56 \\
\hline 9 & 21.1466 .86 & 11.02 & 0.19 & 0.45 & 0.11 & 0.23 \\
\hline 10 & 23.9774 .38 & 0.82 & 0.16 & 0.52 & 0.00 & 0.15 \\
\hline 11 & 42.4854 .82 & 1.52 & 0.20 & 0.82 & 0.00 & 0.16 \\
\hline 12 & 0.77 & 0.39 & 98.41 & 0.02 & 0.17 & 0.01 & 0.23 \\
\hline 13 & 41.76 & 0.11 & 0.34 & 0.00 & 0.63 & 24.87 & 32.29 \\
\hline 14 & 37.64 & 0.36 & 0.39 & 0.06 & 0.94 & 27.9832 .63 \\
\hline 15 & 42.89 & 0.25 & 0.40 & 0.00 & 0.81 & 23.1632 .49 \\
\hline
\end{tabular}

(e)

Figure 12. The SEM/EDS microstructural analysis of the cross-section of the metal produced in exp. 2 (a) and exp. 3 (c) and slag produced in exp. 2 (b) and exp. 3 (d); EDS (e).

The results of elemental analysis of the produced slags indicated that in both cases the dominant phases were calcium aluminates (Figure 12b,d). In experiment 2, in which the proportion of oxides in the slag was $\mathrm{CaO} / \mathrm{Al}_{2} \mathrm{O}_{3}=2$ (Table 1), the chemical composition of the produced slag contained an average of $39.8 \mathrm{wt} . \% \mathrm{Al}, 9.3 \mathrm{wt} . \% \mathrm{Ca}$ and $47.2 \mathrm{wt} . \% \mathrm{O}$ (areas 7, 8 in Figure 12b), which suggests the presence of the $\mathrm{CaAl}_{2} \mathrm{O}_{3}$ phase. The XRD analysis of the slag samples confirmed these results according to the characterized phases in the XRD spectrums shown in Figure 13a. A semi quantitative XRD analysis indicated that about $46 \%$ of the material was $\mathrm{CaO} \cdot \mathrm{Al}_{2} \mathrm{O}_{3}$ and $43 \%$ was $\mathrm{CaO} \cdot 2 \mathrm{Al}_{2} \mathrm{O}_{3}$ phase as the dominant components in slag 2 , which agrees with the $\mathrm{CaO}-\mathrm{Al}_{2} \mathrm{O}_{3}$ binary phase diagram $[48,49]$. 
These findings confirmed the SEM/EDX results above and, in addition the XRD analysis, also showed some minor calcium silicate $\left(\mathrm{CaSiO}_{3}\right)$, which is anticipated in the slag.

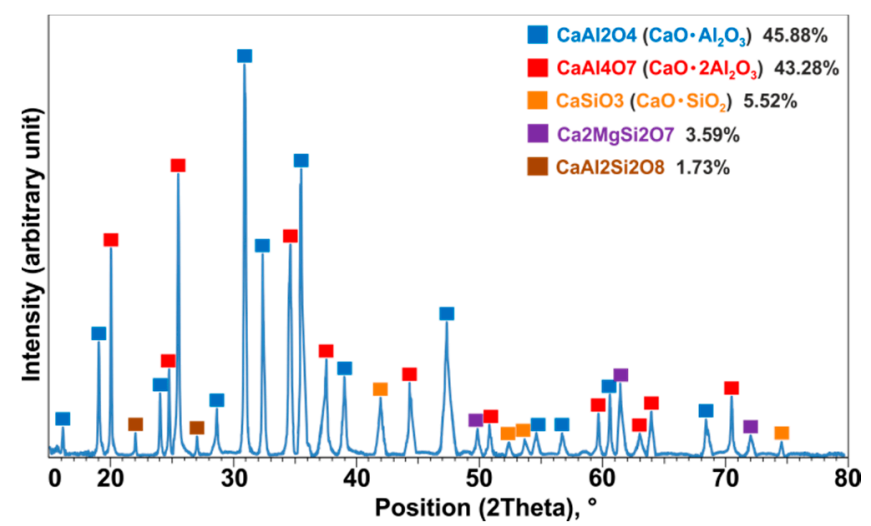

(a)

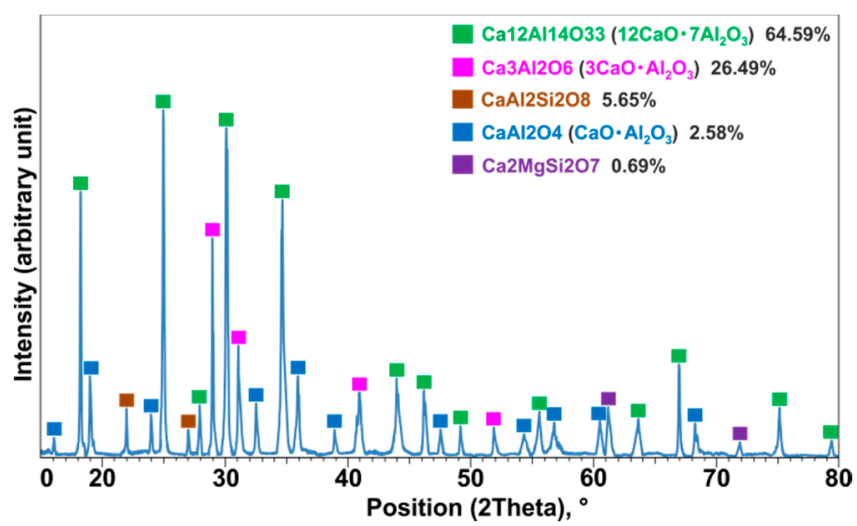

(b)

Figure 13. XRD patterns of the slags product in experiments: 2 (a) and 3 (b).

In the case of experiment 3 , in which the $\mathrm{CaO}$ content was higher with $\mathrm{CaO} / \mathrm{Al}_{2} \mathrm{O}_{3}=4$ (Table 1), the chemical composition of the produced slag contained on average $40.2 \mathrm{wt} . \%$ $\mathrm{Al}, 25.6 \mathrm{wt} . \% \mathrm{Ca}$ and $32.5 \mathrm{wt} . \% \mathrm{O}$ (areas 14, 15 in Figure 12d), suggesting the presence of the $\mathrm{CaAl}_{2} \mathrm{O}_{3}$ intermetallic phase. A semi quantitative $\mathrm{XRD}$ analysis (Figure 13b) indicated that about $64.6 \%$ of the material was $12 \mathrm{CaO} \cdot 7 \mathrm{Al}_{2} \mathrm{O}_{3}$ and $26.5 \%$ was $3 \mathrm{CaO} \cdot \mathrm{Al}_{2} \mathrm{O}_{3}$ phase as the dominant components, which agrees with the results of the EDS (areas 14,15 in Figure 12d) and the $\mathrm{CaO}-\mathrm{Al}_{2} \mathrm{O}_{3}$ binary phase diagram [48,49]. The minor $\mathrm{CaAl}_{2} \mathrm{Si}_{2} \mathrm{O}_{8}$ phase was also identified in an amount of around 5.6\%. Comparing the compositions of $\mathrm{CaO}$ and $\mathrm{Al}_{2} \mathrm{O}_{3}$ in the produced slags 2 and 3 indicates that the chemical and structural properties of the calcium-aluminate slag by-products can be controlled in this process and this can be beneficial for further use of the slags.

\subsection{Metal Recovery and Dross Characterization}

To evaluate the obtained results above, the metal recoveries for the experiments were calculated by mass balances. The known masses of the reactant and product materials and their known/measured concentrations were used. Obviously, the Cu recovery was $100 \%$ as it was in metallic form and it is noble compared with Al. Moreover, if $\mathrm{Cu}$ in the raw materials was in the form of oxide, its recovery was almost complete as the aluminothermic reduction of copper oxides occurred.

When $\mathrm{CaO}-\mathrm{Al}_{2} \mathrm{O}_{3}$ slag was used as the flux, the $\mathrm{Al}_{2} \mathrm{O}_{3}$ of the dross ended up in the final slag. The amount of $\mathrm{Al}_{2} \mathrm{O}_{3}$ in the dross phase could be determined using the final slag composition and mass, and consequently the total metallic $\mathrm{Al}$ in the dross and $\mathrm{Al}$ recovery could be determined. In short, for the exp. 1 scenario, in which no synthetic slag was used, the $\mathrm{Al}$ recovery was only at the level of $39.1 \%$, estimating that the $\mathrm{Cu}-\mathrm{Al}$ alloy in the agglomerated part was about $40 \%$.

Regarding the distribution of metallic $\mathrm{Al}$ of the dross into the produced alloy and separation of $\mathrm{Al}_{2} \mathrm{O}_{3}$ dross into the slag phase, the concentration of metallic $\mathrm{Al}$ in the dross can be determined for the slag-flux aided experiments by the following equation:

$$
\text { metallic } \mathrm{Al} \text { in dross }(\%)=\left(\frac{\text { mass of } \mathrm{Al} \text { in produced alloy }}{\text { total mass of } \mathrm{Al} \text { dross }}\right) \times 100
$$


Moreover, $\mathrm{Mn}$ in dross will end up completely in the metal product as studied previously [7], while Si in dross, which is more metallic, will end up in both metal and slag phases, hence the amount of these elements in the dross can be determined as:

$$
\begin{gathered}
\text { metallic Mn in dross }(\%)=\left(\frac{\text { mass of Mn in produced alloy }}{\text { mass of Al dross }}\right) \times 100 \\
\text { metallic Si in dross }(\%)=\left(\frac{\text { mass of } \mathrm{Si} \text { in produced alloy }+ \text { slag }}{\text { mass of Al dross }}\right) \times 100
\end{gathered}
$$

The amounts of $\mathrm{Al}, \mathrm{Mn}$ and $\mathrm{Si}$ in the utilized dross samples for the two experiments 2 and 3 were determined by mass balance, considering the masses of reactants and products, and also the chemical compositions of the products. It is worth noting that the amounts of the $S i$ in the slags were determined based on the masses of the produced slags and the concentration of the Si-containing phases in Figure 13. The calculated masses of the elements in the dross in experiments 2 and 3 are presented in Figure 14. The data in this figure show that the utilized dross had about $76.5 \% \mathrm{Al}, 15.4 \% \mathrm{Si}$ and $0.7 \% \mathrm{Mn}$, and the non-metallic components were mainly $\mathrm{Al}_{2} \mathrm{O}_{3}$, about $7.3 \%$. The existence of carbide and nitrides in the dross was not detected by the $\mathrm{XRD}$ analysis and this is a fair approximation to consider $\mathrm{Al}_{2} \mathrm{O}_{3}$ as the main non-metallic component. The high concentration of $\mathrm{Si}$ in the dross was due to the existence of Si particles in the dross not being melted during aluminum alloying in the cast house.

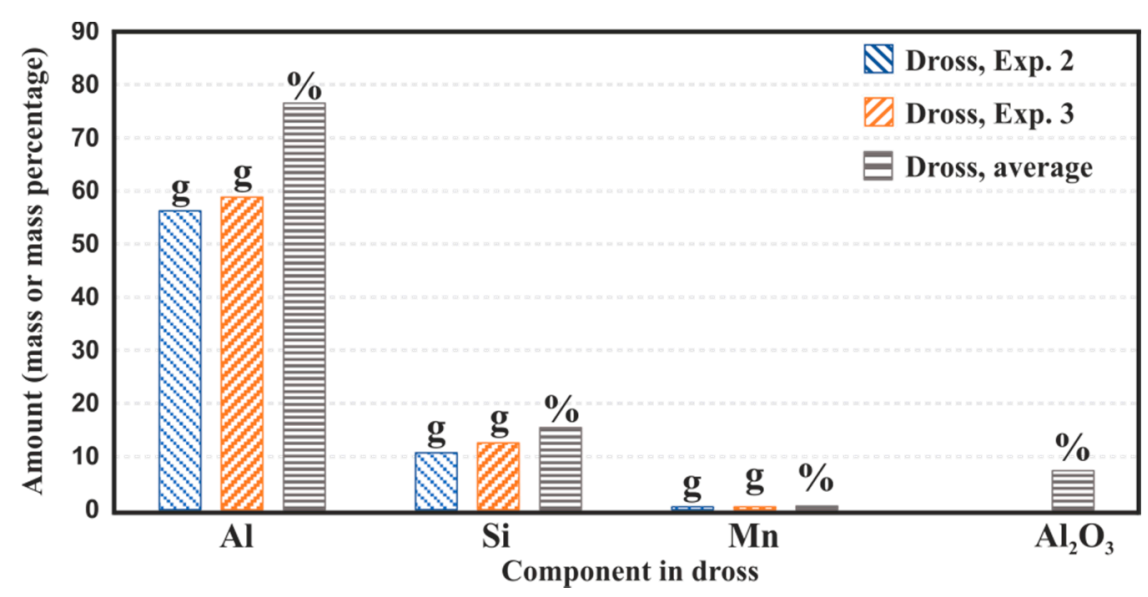

Figure 14. The determined amounts of dross components by mass balance by results of experiments 2 and 3.

\subsection{Process Evaluation}

The recovery of metallic $\mathrm{Al}$ from the AWD was experimentally studied and it was shown that the addition of copper provided better conditions for the Al recovery. Moreover, the process was enhanced via the application of a synthetic slag flux and high-temperature treatment, providing better conditions for the separation of the molten metal and slag phases. The copper use and its mixing with metallic aluminum of the dross yielded an alloy with significantly higher density than $\mathrm{Al}$, which provided better conditions for the physical separation of the produced metal from the slag in molten state. Therefore, we propose an integrated salt-free process for $\mathrm{Al}$ recovery from $\mathrm{Al}$ dross to produce $\mathrm{Cu}-\mathrm{Al}$ alloys for further use or, in another word, $\mathrm{Al}$ recycling, where the $\mathrm{Cu}-\mathrm{Al}$ alloys are used for making specific Al grades. The simplified process is illustrated in Figure 15. The proposed process here has several advantages as compared with the existing treatment process for the AWD. Firstly, it is a simple single stage process in which the materials are melted. It is possible to use a small amount of commercial calcium aluminate slags and skip slag making, or instead of this type of slag utilization, only $\mathrm{CaO}$ (as the flux) is used. When $\mathrm{CaO}$ is used in the melting process, the $\mathrm{Al}_{2} \mathrm{O}_{3}$ of the dross reacts with the added $\mathrm{CaO}$ 
and yields the calcium aluminate slag. The volume of slag produced per unit mass of the metal product depends on the charged materials' characteristics and quantities. This process is also sustainable compared with the salt-based processes, as there is no use of salt and the related precautionary steps that must be considered in materials handling and landfilling. Considering the fact that prevention of waste generation is always better than its valorization, the proposed dross treatment method in this research with no dangerous waste production is an important highlight. On the other hand, different compositions of the $\mathrm{Cu}-\mathrm{Al}$ alloys can be produced, and they could be potentially utilized in the $\mathrm{Al}$ industry to produce the commercial grades of $\mathrm{Al}$ that contains $\mathrm{Cu}$ as an alloying element. In addition, $\mathrm{Cu}$ scrap or even copper oxide can be used in this process; however, the use of copper oxides may yield lower Al recovery. As we observed, if the utilized dross contained Si and Mn elements, the produced alloy contained these elements as well. Hence, the process can be integrated into $\mathrm{Al}$ production plant to recycle metallic components of a dross into the process for the alloy production. The produced slag byproduct is consumable and can be used in other industries such as steelmaking, the cement industry, and even the alumina industry as a feedstock for metallurgical alumina production $[50,51]$.

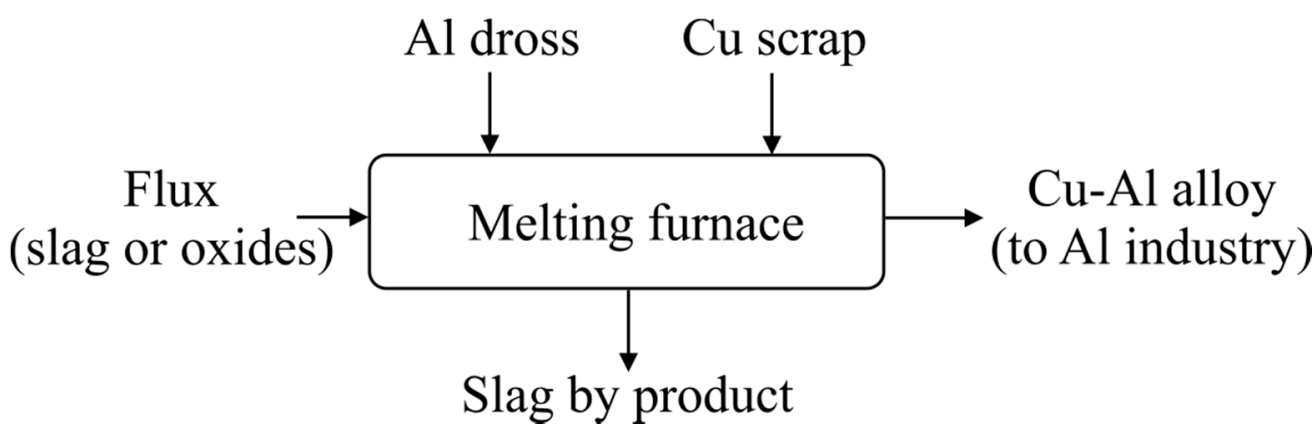

Figure 15. An illustration of the proposed process for $\mathrm{Al}$ dross valorization with $\mathrm{Cu}$ to recover metallic Al.

\section{Conclusions}

The Al recovery from white dross by the remelting with the addition of $\mathrm{Cu}$ with and without oxide flux addition was studied. Moreover, the wettability of Al dross by Al-Cu-Si alloy was experimentally investigated. The main conclusions of the present work can be summarized as:

1. The temperature change in the range of 973-1373 K did not affect the wettability of the Al-Si-Cu alloy/Al dross system; the couple was a non-wettable system with a contact angle in the range of 125-130 degrees.

2. The melting of $\mathrm{Al}$ white dross and $\mathrm{Cu}$ particles yielded (I) an agglomerated fraction of metal and oxide in which the metallic droplets encapsulated in the oxide layer and (II) a completely melted/separated $\mathrm{Cu}-\mathrm{Al}$ alloy settled under the agglomerated portion.

3. The addition of an oxide flux (melted calcium aluminate slags in this study) into the dross and copper mixture led to the complete separation of the metallic and non-metallic components of the dross.

4. In flux-assisted melting of dross and copper, the characteristics of the produced slag depend on the added flux properties and it was found that the phases in produced slag are dependent on the $\mathrm{CaO} / \mathrm{Al}_{2} \mathrm{O}_{3}$ ratio and they can easily be engineered.

5. The applied experimental procedure in the present study can be applied to characterize $\mathrm{Al}$ dross through the separation of metallic components into a $\mathrm{Cu}-\mathrm{Al}$ alloy and non-metallic components into a slag phase.

6. A process for $\mathrm{Al}$ dross and $\mathrm{Cu}$ slag valorization was introduced, which is sustainable and provides onsite recycling of Al from the dross. 
Author Contributions: Conceptualization, J.S. and A.K.; methodology, J.S. and A.K.; software, J.S.; validation, J.S., A.K., I.J. and S.A.; formal analysis, J.S. and A.K.; investigation, A.K. and J.S.; resources, J.S., A.K., I.J. and S.A.; data curation, J.S. and A.K.; writing-original draft preparation, J.S. and A.K.; writing-review and editing, J.S., A.K., I.J. and S.A.; visualization, A.K. and J.S.; supervision, J.S.; project administration, J.S. and A.K.; funding acquisition, J.S. All authors have read and agreed to the published version of the manuscript.

Funding: This research was funded by SFI Metal Production (Centre for Research-based Innovation), grant number 237738. The APC was funded by SFI Metal Production.

Institutional Review Board Statement: Not applicable.

Informed Consent Statement: Not applicable.

Data Availability Statement: Data available in a publicly accessible repository that does not issue DOIs. Publicly available datasets were analyzed in this study. This data can be found here: https: / / www.ntnu.edu/metpro (accessed on 23 July 2021).

Acknowledgments: This publication has been funded by the SFI Metal Production (Centre for Research-based Innovation, 237738). The authors gratefully acknowledge the financial support from the Research Council of Norway and the partners of the SFI Metal Production.

Conflicts of Interest: The funders had no role in the design of the study; in the collection, analysis, or interpretation of data; in the writing of the manuscript; or in the decision to publish the results. On behalf of all the authors, the corresponding author states that there is no conflict of interest.

\section{References}

1. Sahu, O. Suitability of aluminum material on sugar industry wastewater with chemical and electrochemical treatment processes. Int. J. Ind. Chem. 2019, 10, 335-347. [CrossRef]

2. Bajare, D.; Korjakins, A.; Kazjonovs, J.; Rozenstrauha, I. Pore structure of lightweight clay aggregate incorporate with non-metallic products coming from aluminum scrap recycling industry. J. Eur. Ceram. Soc. 2012, 32, 141-148. [CrossRef]

3. Kudyba, A.; Akhtar, S.; Johansen, I.; Safarian, J. Aluminum recovery from white aluminum dross by a mechanically activated phase separation and remelting process. JOM 2021. [CrossRef]

4. Tsakiridis, P.E. Aluminium salt slag characterization and utilization-A review. J. Hazard. Mater. 2012, 217, 1-10. [CrossRef] [PubMed]

5. Tabereaux, A.T.; Peterson, R.D. Chapter 2.5-Aluminum Production. In Treatise on Process Metallurgy; Seetharaman, S., Ed.; Royal Institute of Technology: Stockholm, Sweden, 2014; Volume 3, pp. 839-917.

6. Mandin, P.; Wüthrich, R.; Roustan, H. Industrial Aluminium Production: The Hall-Heroult Process Modelling. ECS Trans. 2009, 19, 1-10. [CrossRef]

7. Kudyba, A.; Akhtar, S.; Johansen, I.; Safarian, J. Aluminothermic Reduction of Manganese Oxide from Selected MnO-Containing Slags. Materials 2021, 14, 356. [CrossRef]

8. International Aluminum Institute. Available online: https:/ / www.world-aluminium.org/statistics/ (accessed on 10 June 2021).

9. Jafari, N.H.; Stark, T.D.; Roper, R. Classification and reactivity of secondary aluminum production waste. J. Hazard. Toxic Radioact. Waste 2014, 18, 04014018. [CrossRef]

10. Adeosun, S.O.; Sekunowo, O.I.; Taiwo, O.O.; Ayoola, W.A.; Machado, A. Physical and Mechanical Properties of aluminum dross. Adv. Mater. 2014, 3, 6-10. [CrossRef]

11. Verma, S.K.; Dwivedi, V.K.; Dwivedi, S.P. Utilization of aluminium dross for the development of valuable product-A review. Mater. Today Proc. 2021, 43, 547-550. [CrossRef]

12. Manfredi, O.; Wuth, W.; Bohlinger, I. Characterizing the physical and chemical properties of aluminum dross. JOM 1997, 49, 48-51. [CrossRef]

13. Masson, D.B.; Taghiei, M.M. Interfacial Reactions between Aluminum Alloys and Salt Flux during Melting. Mater. Trans. 1989, 30, 411-422. [CrossRef]

14. Maung, K.N.; Yoshida, T.; Liu, G.; Lwin, C.M.; Muller, D.B.; Hashimoto, S. Assessment of secondary aluminum reserves of nations. Resour. Conserv. Recycl. 2017, 126, 34-41. [CrossRef]

15. Shinzato, M.C.; Hypolito, R. Effect of disposal of aluminum recycling waste in soil and water bodies. Environ. Earth Sci. 2016, 75, 628. [CrossRef]

16. Lucheva, B.; Tsonev, T.; Petkov, R. Non-waste aluminium dross recycling. J. Univ. Chem. Technol. Metall. 2005, 40, 335-338.

17. Tsakiridis, P.E.; Oustadakis, P.; Agatzini-Leonardou, S. Aluminium recovery during black dross hydrothermal treatment. J. Environ. Chem. Eng. 2013, 1, 23-32. [CrossRef]

18. Meshram, A.; Singh, K.K. Recovery of valuable products from hazardous aluminum dross: A review. Resour. Conserv. Recycl. 2018, 130, 95-108. [CrossRef] 
19. Kondoh, K.; Kawakami, M.; Imai, H.; Umeda, J.; Fujii, H. Wettability of pure Ti by molten pure Mg droplets. Acta Mater. 2010, 58, 606-614. [CrossRef]

20. Young, T. An essay on the cohesion of fluids. Phil. Trans. Roy. 1805, 95, 65-87.

21. Sobczak, N.; Singh, M.; Asthana, R. High-temperature wettability measurements in metal/ceramic systems-Some methodological issues. Curr. Opin. Solid State Mater. Sci. 2005, 9, 241-253. [CrossRef]

22. Sobczak, N. Improvement of wetting in metal/ceramic systems. In Interfacial Science in Ceramic Joining; NATO ASI Series; Bellosi, A., Kosmac, T., Tomsia, A.P., Eds.; Kluwer: Berkeley, CA, USA, 1998; Volume 58, pp. $27-42$.

23. Eustathopoulos, N.; Sobczak, N.; Passerone, A.; Nogi, K. Measurements of contact angle and work of adhesion at high temperature. J. Mater. Sci. 2005, 40, 2271-2280. [CrossRef]

24. Kudyba, A.; Sobczak, N.; Budzioch, J.; Polkowski, W.; Giuranno, D. Improvements in experimental investigation of molten Mg-based materials. Mater. Des. 2018, 160, 915-917. [CrossRef]

25. Kudyba, A.; Sobczak, N.; Polkowski, W.; Bruzda, G.; Polkowska, A.; Giuranno, D. Improved methodological concepts for processing liquid Mg at high temperature. J. Magnes. Alloy. 2021, 9, 183-191. [CrossRef]

26. Eveno, M.; Duran, A.; Castaing, J. A portable X-ray diffraction apparatus for in situ analyses of masters' paintings. Appl. Phys. A 2010, 100, 577-584. [CrossRef]

27. Azof, F.I.; Jinglin You, K.T.; Safarian, J. Synthesis and Characterization of $12 \mathrm{CaO} \_7 \mathrm{Al}_{2} \mathrm{O}_{3}$ Slags: The Effects of Impurities and Atmospheres on the Phase Relations. Metall. Mater. Trans. B 2020, 51, 2689-2710. [CrossRef]

28. Zobac, O.; Kroupa, A.; Zemanova, A.; Richter, K.W. Experimental Description of the Al-Cu Binary Phase Diagram. Metall. Mater. Trans. A 2019, 50, 3805-3815. [CrossRef]

29. Sobczak, N.; Ksiazek, M.; Radziwill, W.; Asthana, R.; Mikulowski, B. The effect of temperature, matrix alloying and substrate coatings on wettability and shear strength of $\mathrm{Al} / \mathrm{Al}_{2} \mathrm{O}_{3}$ couples. Metall. Mater. Trans. A 2004, 35, 911. [CrossRef]

30. Sobczak, N.; Stobierski, L.; Radziwill, W.; Ksiazek, M.; Warmuzek, M. Wettability and interfacial reactions in $\mathrm{Al}_{\text {/TiO }}$. Surf. Interface Anal. 2004, 36, 1067-1070. [CrossRef]

31. Sobczak, N.; Sobczak, J.; Seal, S.; Morgiel, J. TEM examination of the effect of titanium on the Al/C interface structure. Mater. Chem. Phys. 2003, 81, 319-322. [CrossRef]

32. Sobczak, N.; Oblakowski, J.; Nowak, R.; Kudyba, A.; Radziwill, W. Interaction between liquid aluminum and NiO single crystals. J. Mater. Sci. 2005, 40, 2313-2318. [CrossRef]

33. Laurent, V.; Chatain, D.; Eustathopoulos, N. Wettability of SiC by aluminium and Al-Si alloys. J. Mater. Sci. 1987, 22, 244-250. [CrossRef]

34. Sobczak, N.; Asthana, R.; Radziwill, W.; Nowak, R.; Kudyba, A. The role of aluminium oxidation in the wetting-bonding relationship of Al/oxide couples. Arch. Metall. Mater. 2007, 52, 55-65.

35. Morgiel, J.; Sobczak, N.; Pomorska, M.; Radziwill, W.; Nowak, R.; Kudyba, A.; Wojewoda-Budka, J. TEM investigation of reaction zone products formed between molten $\mathrm{Al}$ and $\mathrm{CoO}$ monocrystalline substrate. J. Microsc. 2010, 237, 299-303. [CrossRef]

36. Wojewoda-Budka, J.; Sobczak, N.; Morgiel, J.; Nowak, R. Reactivity of molten aluminium with polycrystalline ZnO substrate. J. Mater. Sci. 2010, 45, 4291-4298. [CrossRef]

37. Wojewoda-Budka, J.; Sobczak, N.; Morgiel, J. Interactions between molten aluminum and $\mathrm{Y}_{2} \mathrm{O}_{3}$ studied with TEM techniques. J. Microsc. 2010, 237, 253-257. [CrossRef] [PubMed]

38. Sobczak, N.; Gorny, Z.; Ksiazek, M.; Radziwill, W.; Rohatgi, P.K. Interaction Between Porous Graphite Substrate and Liquid or Semi-Liquid Aluminium Alloys Containing Titanium. Mater. Sci. Forum 1996, 217-222, 153-158. [CrossRef]

39. Hashim, J.; Looney, L.; Hashmi, M.S.J. The wettability of SiC particles by molten aluminium alloy. J. Mater. Process. Tech. 2001, 119, 324-328. [CrossRef]

40. Seal, S.; Barr, T.L.; Sobczak, N.; Kerber, S.J. Microscopy and electron spectroscopic study of the interfacial chemistry in Al-Ti alloy/graphite systems. J. Mater. Sci. 1998, 33, 4147-4158. [CrossRef]

41. Liu, Z.; Yang, J.; Li, Y.; Li, W.; Chen, J.; Shen, L.; Zhang, P.; Yu, Z. Wetting and spreading behaviors of Al-Si alloy on surface textured stainless steel by ultrafast laser. Appl. Surf. Sci. 2020, 520, 146316. [CrossRef]

42. Klinter, A.J.; Leon-Patino, C.A.; Drew, R.A.L. Wetting phenomena of Al-Cu alloys on sapphire below $800{ }^{\circ} \mathrm{C}$. Acta Mater. 2010, 58, 1350-1360. [CrossRef]

43. Kobashi, M.; Kuno, S.; Choh, T.; Shimizu, T. The Effect of Surface Active Elements on the Wetting Behavior of Iron by Molten Aluminum Alloy. ISIJ Int. 1995, 35, 488-493. [CrossRef]

44. Mao, W.; Noji, T.; Teshima, K.; Shinozaki, N. Wettability of Molten Aluminum-Silicon Alloys on Graphite and Surface Tension of Those Alloys at $1273 \mathrm{~K}\left(1000{ }^{\circ} \mathrm{C}\right)$. Metall. Mater. Trans. A 2016, 47, 3201-3212. [CrossRef]

45. Siewiorek, A.; Sobczak, N.; Sobczak, J.; Kudyba, A.; Kozera, R.; Boczkowska, A. High-Temperature Interaction Between Molten AlSr10 Alloy and Glass-Like Carbon Substrate. J. Mater. Eng. Perform. 2016, 25, 3348-3357. [CrossRef]

46. Shen, P.; Fujii, H.; Matsumoto, T.; Nogi, K. Reactive wetting of $\mathrm{SiO}_{2}$ substrates by molten Al. Metall. Mater. Trans. A 2004, 35, 583-588. [CrossRef]

47. Shen, P.; Fujii, H.; Matsumoto, T.; Nogi, K. Wetting and reaction of MgO single crystals by molten Al at 1073-1473 K. Acta Mater. 2004, 52, 887-898. [CrossRef]

48. Hallstedl, B. Assessment of the $\mathrm{CaO}-\mathrm{Al}_{2} \mathrm{O}_{3}$ System. J. Am. Ceram. Soc. 1990, 73, 15-23. [CrossRef]

49. Jerebtsov, D.A.; Mikhailov, G.G. Phase diagram of $\mathrm{CaO}-\mathrm{Al}_{2} \mathrm{O}_{3}$ system. Ceram. Int. 2001, 27, 25-28. [CrossRef] 
50. Azof, F.I.; Safarian, J. Leaching kinetics and mechanism of slag produced from smelting-reduction of bauxite for alumina recovery. Hydrometallurgy 2020, 195, 105388. [CrossRef]

51. Azof, F.I.; Yang, Y.; Panias, D.; Kolbeinsen, L.; Safarian, J. Leaching characteristics and mechanism of the synthetic calciumaluminate slags for alumina recovery. Hydrometallurgy 2019, 185, 273-290. [CrossRef] 